\title{
Guds orden og H.C. Andersens teologi
}

Michael Agerbo Mørch indleder dette nummer af Dansk Teologisk Tidsskrift med en artikel, der forsvarer, at vi fortsat taler om Guds 'uforanderlighed', skønt dette begreb ofte er blevet stærkt kritiseret i moderne teologi, som har hævdet, at det rummer en metafysik, der er hentet fra græsk filosofi og står i modsætning til kristendommens levende, dynamiske Gud, der er passioneret til stede i sine relationer til skaberværket. Ved hjælp af udtrykket 'uforanderligt passioneret' vil Mørch i stedet vise, at uforanderlighed og relationel tilstedeværelse kan forenes gennem en trinitarisk tænkning, hvor Gud kan være uforanderligt passioneret i sin immanente trinitet, der rummer en række fuldt ud realiserede 'passionsmodi', men hvor Gud samtidig, i sin økonomiske trinitet, kan aktivere de enkelte modi i forhold til skabningen - på forskellig vis ud fra hvilken relation han har til denne. Der sker således en reel forandring i Gud, men således at denne forandring er udtryk for den 'emotionelle konstans', som hans væsen er.

Jonas Kjøller-Rasmussen undersøger og sammenligner tre danske prædikener til anden søndag efter helligtrekonger (perikopen Brylluppet i Kana), to senmiddelalderlige af hhv. Peter Madsen og Christiern Pedersen og én reformatorisk af Hans Tausen. Kjøller-Rasmussens undersøgelse knytter til ved to forudsætninger for forståelse: For det første en kontekstualiserende læsning, idet enkeltprædikenerne ikke blot må ses som selvstændige tekster, men også som dele af større, sammenhængende tekster, dvs. prædikensamlingerne. For det andet en opblødning af periodiseringerne, så historien ikke tænkes i blokke fx middelalder og tidlig moderne periode med reformationen som grænsemarkør. Det viser sig da, at der gennem alle tre prædikener foreligger den samme helt grundlæggende kerne i forståelsen af ægteskabet som godt og gudsskabt. Hos Madsen og Pedersen opfattes ægteskabet dog som en orden af samme art som andre religiøse ordener, og derved relativeres det også. Hos Tausen er denne sammenhæng fjernet, således at æxteskabets godhed er af absolut karakter. Prædikenerne læses på denne måde i lyset af prædikensamlingernes særegne karakter og på tværs af det reformatoriske spænd, og Kjøller-Rasmussens studie demonstrerer således det frugtbare ved et kontekstualiserende, transreformatorisk metodisk greb. 
Dernæst følger tre oppositionsindlæg ved Kaj Mogensens forsvar for sin teologiske doktordisputats om H.C. Andersens teologi.

Kirsten Nielsen bringer indledningsvis en bifaldende gengivelse af afhandlingens tese og indhold, men stiller efterfølgende også en række kritiske spørgsmål til afhandlingens metodeafsnit og diskuterer hermeneutiske spørgsmål vedrørende forfatterintention og de forskellige intertekster, der spiller en rolle for fortolkningen af de konkrete tekster. Nielsens diskussion udbygges også konkret i forhold til nogle af Mogensens tekstanalyser, der drejer sig om fire af Andersens digte.

Mogens Pahuus diskuterer Mogensens gengivelse af de centrale elementer i Andersens livssyn og teologi og skelner her på den ene side mellem Andersens opfattelse af Gud som et kærligt forsyn og på den anden side spændingen mellem Andersens forståelse af den menneskelige skæbne som ledet af Gud og som bestemt af dets egen frihed gennem stræben og udvikling. Efter Pahuus' mening har Mogensen ikke i tilstrækkelig grad blik for vanskelighederne ved Andersens forsynstanke eller muligheden for at fortolke den på forskellige måder, og han har heller ikke tilstrækkelig forståelse for betydningen af menneskets frihed hos Andersen. Dette søger Pahuus at vise gennem en behandling af en række af Andersens tekster - bl.a. et eventyr, tre romaner og et digt. Afsluttende betvivler Pahuus, at Andersens tanker om udødelighed og forsyn stadig har en nutidig relevans; meget har karakter af postulat, og fra Mogensens side mangler der en argumentation for, hvorledes Andersens forsynstanke lader sig forene med en anerkendelse af menneskets frihed.

Både foranlediget af Mogensens teologiske tilgang til Andersens forfatterskab og, mere specifikt, af et afsnit om Andersens 'salmer' i afhandlingens anden del forholder Jorgen Kjergaard sig på et kirkehistorisk-hymnologisk grundlag til Mogensens analyser af to salmer, som Andersen skrev til genindvielsesfesten i Holmens Kirke i 1836. Kjærgaard mener, at Mogensen ikke har haft øje for muligheden af, at Andersens salmer kan repræsentere 'en klassisk luthersk menighedsforståelse' og være inspireret af datidens dåbsritual. Kjærgaard tænker sig, at Andersens menighedssyn kan skyldes påvirkninger fra flere kanaler, fra Mynster, indirekte fra Grundtvig og måske fra en salmetradition fra før rationalismen. 